\title{
Coastal Erosion Mitigation Based Community Empowerment Strategies in Jerowaru District of East Lombok Regency, West Nusa Tenggara Province, Indonesia
}

\author{
Dewi Ramadhan \\ Graduate Student of Geography Education, Social Science Faculty, Universitas Negeri Padang \\ Email: ramadhandewi743@gmail.com
}

\begin{abstract}
The purpose of this research was to analyze and formulate alternative form of coastal erosion mitigation by using AHP analysis (Analythical Hierarchy Process) and formulate empowerment strategies of coastal erosion response community in Jerowaru district of East Lombok Regency. This research was descriptive qualitative research which used observation, interview and documentation as intruments of data collection. Two types of data were used, namely primary data and secondary data. Data was analyzed by using AHP and SWOT. The result of this research found that there were 6 criteria of coastal erosion mitigation. They are: community empowerment $(0,444)$, Mangrove trees Cultivation $(0,234)$, settlement relocation $(0,153)$, Environment control $(0,85)$, Grid stone $(0,53)$, government's role $(0,31)$. The strategy used to prevent the erosion was Grid stone installation in coastal erosion mitigation, a routine public counseling, improving community awareness of coastal area preservation, the relocation of community settlement which was affected by coastal erosion and preventing the development of settlements in the areas prone to coastal Erosion.
\end{abstract}

Keywords: Community Empowerment Strategy, Coastal Erosion Mitigation.

\section{Introduction}

East Lombok is one of Administrative areas of West Nusa Tenggara. Its long coastal line and its direct border to the sea make coastal area in Lombok timur rapidly changes its landscape.The effect of tide on coastal areas is one of natural consequences. Tidal activity of the sea on coastal area creates coastal erosion and damages building alongside the beach (Triatmodjo, 1999). Coastal erosion happens in some districts in East Lombok Regency. One of them is Jerowaru District. In Jerowaru coastal erosion results in severe erosion, for example in Selong beach. Due to the erosion, about 5 to 6 hectars of community plantation were damaged. Erosion endanger community settlement and farm land (Lombok Kita, 2015).

The damage is the result of strong wave and current motion pattern of Alas Strait that scrape the land. Moreover, people ignorance toward coastal protection area policy which prohibit the community settlement located on the area 100 meters from the shore also makes the damage impossible to be avoided. This policy is made by Public Works Departmentrelated to the regulation of urban coastal space utilization (2009). The regulation also mentions the prohibition of residential areas specified in the neighborhood and citizens Association, regency and city to be located in the disaster prone areas (e.g landslide, flood, erosion and erosion). In the field, there are many houses that are settled in the abrasio prone areas despite the fact that erosion is categorized as one of disasters. As defined by Constitution number 24 year 2007, disaster is an event or series of events that threaten and disrupt the life and livelihood of the community caused by either natural or human factors resulting in the occurrence of human casualties, environmental damage, property 
loss, and psychological impact.As citizens, people affected by erosion also have the right to feel comfortable and secure in their lives. They should live in an environment that is spared from coastal erosion disasters.However, the people in Jerowaru continue to feel the fear of the time when the storms and big waves crash into their houses. The people who live along the coastline are the protagonists who are firstly stricken by coastal erosion. They also play an important role in the effort to deal with coastal erosion issues. Community Empowerment is one of manifestations of government's mission because community empowerment is done to provide the community skills in maintaining the sustainability of the environment where they live (Julius, 2015).

\section{Method}

This research was a descriptive qualitative research which used observation, interview, and documentation study as intruments to collect desired data. The researcher collected primary and secondary data from darigoverment agencies in East Lombok Regency, BPS (Central Bureau of Statistics in Indonesia) and BAPPEDA (Development Planning Agency at Sub-National Level in Indonesia). primary data was collected through deep interviews and conducting observation or open observation regarding concerning enviromental condition due to coastal erosion disasters in Jerowaru District. The secondary data was obtained from National Board for Disaster Management (BNPB) and Development Planning Agency at Sub-National Level (BAPPEDA) including informations from the newspapers, monographic data, and regional informations from the internet and published documents by relevant agencies. The informants of this research were the local community. To analyze the data about the manifestation of coastal erosion mitigation, the researcher used AHP (Analytical Hierarchy Process) method (Saaty, 2001). For the data of community empowerment strategies, the researcher use SWOT analysis (Rangkuty, 2006).

\section{Result and Discussion}

\section{Impact and Mitigation of Coastal Erosion}

Erosion is a destructive process of coastal erosion by ocean waves and currents. Abrasi is also called coastal erosion. Coastline damage due to erosion is triggered by disruption of the natural balance in the coastal area. Although erosion is usually caused by natural phenomena, humans can also be the main cause of erosion (IRBI, 2013). The erosion strength is determined by the magnitude of the waves that slam into the shore. Large wave energy will cause strong waves that slam into the coast, which can form a destructive wave that have a high altitude and velocity.Before the beach sands absorb the water of the incoming waves, the next wave with a higher amount of water returns to the coast and a great deal of water will accumulate and transport the coastal material to the sea. This is what happened in Jerowaru beach where coastal erosion occurs because of the waves and the damage of it is detrimental to the community (Delgado, 2015).

Coastal erosion can subvert the trees due to its wave hits. Erosion can also destroy coral reef ecosystem. Coastal erosion has been disadventageous to the community. The secondary data showed that erosion had damaged infrastucture such as highway in Selong area, hundreds of meters road and embankment at the seaside were collapsed due to erosion. Agricultural lands owned by the local people were continously decreased from year to year. Economically, the income of the people who work as fishermen decreased due to the difficulty of canal parking or transportation fund.In addition, until now, the owner of farms near the coast do not have a clear fate (Subaidi, 2017). Coastal erosion have been the major proble for coastal areas. It damages the development of coastline and treathen economic and social welfare of the community that relies on the coastal livehood (A.M. Mwakumanya, 2009). 
The local government has provided solutions to coastal erosion issues such as building a coastal overpass to anticipate the occurrence of erosion and tidal waves as installing breakwaters at several points. Moreover, another solution in by constructing a 700-meter-long road in erosion-pone areas. However, this solution was not effective because the waves are higher than the road. The data from interviews with the local community and secondary data revealed that the people wanted government to be serious in dealing with abrassion issues since a big loss experienced by the local community such as damages on the road, bridge, and on the argricultural lands (Hartono, 2017).

\section{Alternative mitigation of coastal erosion disaster}

Based on the information collected in this research, there found some alternative mitigation of coastal erosion disaster occured in Jerowaru District.

Coastal Erosion Mitigation in Jerowaru could be in form of:

1. Mangrove Cultivation

2. Constructing Stone Grid

3. Environmental control

4. Community empowerment

5. Government's role

6. Settlement Relocation

By using AHP scoring criteria (Saaty, 1993), the scoring was done on the data collected from the respondents. These relative comparison values are processed through matrix manipulation or through solving mathematical equations to determine the relative ranking of all available alternatives. The criteria was chosen by cosidering the value weights of each alternative of coastal erosion mitigation. The analysis was done if the consistency ratio value of paired criteria $<0.1$. After doing the analysis, the criteria shoule be:

1. Community empowerment $(0,444)$

2. Mangrove Cultivation $(0,234)$

3. Settlement relocation $(0,153)$

4. Environmental control $(0,85)$

5. Stone Grid $(0,53)$

6. Government's role $(0,31)$

\section{Communty Empowerment}

Community emporwerment is the manifestation of the development of community capacity so that the people could understand their rights and obligations (Vitayala, 2015). Community empowerment aims to engage the community to manage coastal areas. By doing so, it is hope for the community to be responsible with the coastal areas near their houses. Sustainable coastal area managemet can be realized by approaching the ecosystem and using integrated research on the ecosystem with the helps from global or regional communities by considering socio-economic condition of the community (Kristiayanti, 2016). In the priority scale of calculated alternatives, Community empowerment got highest score. Community empowerment is very needed by the local community at this time in Jerowaru District. The reason is Community Empowerment can make people in Jerowaru tougher in dealing with coastal erosion.

\section{Mangrove Cultivation}

Magrove forest is aimed to prevent erosion, oxygen producer, and is an important partin aquatic ecosystem. Various types of marine animals live in this area or are very dependent on the existence of 
mangrove ecology. Mangrove ecology is well-known to have a fuction as a nursery ground of various high-priced aquatic animals such as fishes, prawn, crab,and clam.Another important function of mangrove forest is to help protecting the coastline stability. If coastline stability was not protected, the coastline would decrease from year to year. Then, it can also cause damage to the land and the beach where there wil be erosion caused by sea water. This can also narrow and erode the land that it will certainly treathen the life aroun the coast (Spalding et al, 2014).

By preserving mangroves forest, Tsunami's effect can be prevented or at least it can reduce the destructive impacts of Tsunami. Mangroves can also reduce tidal waves. The main reason why mangroves could prevent Tsunami is because plants of Mangrove forest is very capable in reducing tidal waves. When the tide increases, mangroves can reduce at least $60 \%$ the impact of it. So, it is very reasonable to say that mangrove forests can reduce the bad impacts of Tsunami and high tides (Thampanya, 2006). Mangroves can reduce erosion. Erosion is the process of soil and land erosion which is generally caused by sea waves. When the land is frequently scraped by sea water, it will cause erosion. So, the land become narrower and eroded. This can lead to a decrease ofaland, and can cause sea water to easily rise to the surface.Mangrove forest is what keeps this from happening. With the existence of mangrove forests as a shield of a land from the sea waves, then the possibility of erosion can be minimized. Knowing the significant role of mangrove forest, people shoud be aware and start conserving mangrove forest in order to be avoided from coastal erosion (Aflaha, 2014).

\section{Settlements relocation}

The local community in Jerowaru District very much aware of the importance of living in the safe areas, protecting residential areas through vegetation, mangrove forests, andearly warning system. Related to the relocation of community residence which suffered sever damage due to coastal erosion, the government should ask for input from the people from that area (The Regulation of Ministry of Pulic Housing 2014).

\section{Enviromental control}

The people who live in the coastal areas plays an important role in coping with the problem related to coastal erosion. The people should participate in constructing process, policy-making, monitoring the development of the construction and preserving the coastal enveronment. The community should control the activities that could damage coastal environment and take a good care of the coastal environment.

\section{Stone grid construction}

One of the ways to cope with coastal erosion is by constructing coastal protection building (jetty, groyne, stone grid, revetment, and offshore breakwater system). Groyne is a coastal protection structure which is constructed perpendicular to the coastline, and its function is to hold sendiment transport along the shore so it can reduce/stop the erosion. This structure also prevent sendiment transport to the port or estuary. Revetment is aconstruction that separate the land from the sea. It works as a coastal protection from erosion and wave attacks. It protects the buildings right behind the contruction. The surface of the structure which face the waves could be vertical or sloping. Offshore breakwater system is a structure that is built in aline with the shore and have certain distance from the coastline. The sructure is aimed to protect the lands behind it from the wave attack. This system can be in form of one building or a couple of buildings which consist of several breackwater systems that is separated by certain gaps. Stone grid construction is aimed to protect coastal areas that have serious erosion problem (Ray-Yeng Yang, 2012). The existence of the structures or buildings projected to or parallel with the shoreline will give a significant effect to coastline shape. Coastal protection buildings is constructions which aim to protect the beach/shore from destructive sea waves and currents (Triadmodjo, 1991) 


\section{Government's role}

Disaster management is every party's responsiblity. This is a form of paradigm shifting of legalized constitution number 27 year 2007 related to Disaster Management (UU 24/2007). The effort to manage disasters should involve all interested parties for the sake of nation thoughness in facing disaster. One of disasters in Jerowaru District is coastal erosion. Government's role in reducing risks of the disaster is very crucial. development process, policy-making, monitoring result of development, and policy enforcement are what drive the success of an effective and eficient development. So, there is a good cooperation between govenrment and society in overcoming the impact of coastal erosion.

Three pillars (actor) of disaster management are central and local government, community, and business institutions. Central and local governement are responsible for organizing disaster management. This responsibility is especially assigned to National Board for Disaster Management in central level (BNPB) and Regional Disaster Mangement Agency (BPBD). BPBD is responsible for disaster management, setting standarization and needs of disaster management, providing and directing the community based on geovernment and BPBD regulation concerning disaster management such as preparing, establishing, and informing the community about disaster-prone map, preparing and establishing a permanent disaster management procedures, implementing disaster management program in its area, reporting the activity of disaster management to the District head once a monthin normal situation and any time in emergency situation, controlling the collection and the distribution of money and goods, being responsible for the use of funds received from regional income and expenditure budgets (APBD), and performing other regulation in accordance with the laws and regulation (Pristianto, 2012).

\section{Community Empowerment Strategies of Coastal Erosion Response}

The implementation strategies are designed based on the characteristics of each alternative criteria by considering environmental physical factors and socio-cultural factors. The alternative criteria are:

1. Installation of Grid Stone in Coastal Erosion mitigation

Mitigation is needed for erosion areas in order to be ready to face the erosion. An exampl of mitigation is by using Grid Stone. This construction is able to reduce the impact of abrassion for a long period of times (Triadmojo, 2008).Breakwater in the form of stonepiles is built up in layers. Outer layer is composed of biggest and heaviest rock ad the deeper the layer is the smaller the stones that compose its construction. The reason for such composition is that the outer layer of the construction will receive the strongest force of the waves. So, wiegh and size of the stone should be considered to maintain the balance of the construction. Another reason is the cost of the stones. Big and heavy rocks cost much money, so the inner layer of the grid can be filled by smaller stones. The main requirement of the material size used in the inner layer is that it should not be washed through the pores or outer cavity (Natural Resources Land Division and Department, Coastal Lands Program Hawai, 2000).

2. Routine Community Counseling/Communiy Empowerment

Materials of the counseling are not only related to physical condition of the coastal area but also related to people knowlede and awareness toward the importance of cooperation in coping with coastal abrasio issues. Community counseling is conducted by the stakeholders such as government, nor-governmental organizations (LSM), urban village head, sub-district head, and the society (Ftriansyah, 2012). The impact of coastal erosion is mostly felt by the people who inhabit the coastal areas. The majority of people are fisherman community whose their income is from coastal and marine resources. The damage of coastal areas results in the catch decreases day by day and it also affect their income and quality of life so the image of proverty increasingly attach to fishing community. The proverty also forces them to exploit fishery and marine resources by using the techniques that could destroy its sustainability for example magrove logging, reef mining or fishing by using illegal equipments that can damage marine 
evironment. To prevent those things from happening, the government or other stakeholders should do community counseling and community empowerment about coastal erosion (P. Helman, 2010).

3. Raising community's awareness about the preservation od coastal areas

Coastal areas are transitional areas of land and water (ocean). The changes of coastal areas are affected by the changes and pressures of land and sea. An advanced coast area management could be realized through integrated aproach and research on the ecosystem, for example through raising people awareness toward their socio-economical situation. To enhance coastal area preservation in Jerowaru District, the governement can organize an advance development such as economic development, ecosystem-and-community-based beneficiaries of coastal areas (Coral Reef Conservation Program 2011-2016 Strategic Plan, Office of Coastal and Aquatic Managed Areas Florida Department of Environmental Protection, 2011). Community-based management of coastal areas could be defined as a management system of natural resources in an area where the local community actively involve in managing the natural resources in that place. Goverment's past policy direction that prioritized urban community development and agricultural development in the countryside, made coastal community remained unnoticed. Today's policy direction should pay the same attention on coastal community, for example, by doing coastal community empowerment. Community empowerment should not be focus on providing the community with money and goods but should be in form of counseling or training and accompaniment of natural resources management and enviromental preservation. A continous and consistent practice of the trainings and accompaniments will improve the ability of coastal community to independently manage natural resources and preserve their environment (Nopparat Nasuchon, 2009).

4. The relocation of settlements that are affected by coastal erosion and preventing residential development in erosion-prone areas.

The relocation can be done through optimizing government's performance in countermeasures of coastal erosion.Government should organize the residential area of coartal community based on the regulation of regional spatial so that the impact of coastal erosion can be minimized (Alif Noor Anna, 2014).If coastal erosion conditions get worse, the community should relocate their houses to safer area. Community and government should work together for the sake of conserving coastal areas and amenities of the people who live in coastal areas. The implementation of relocation is mostly depend on agreement between community and relocation team who are ddirected by BPPD (Development Planning Agency at Sub-National Level) (Juanda, 2017).

5. Growing mangrove forests in mangorave habitation

One of ways to conserve coastal environments is throuh reforestation of coastal areas for example mangrove cultivation. Mangrove cultivation can accelerate coastal growth because their root are going to keep the sendiment/mud from being swept away by the currents and waves so that the sendimen/mud will be settled around the mangrove trees. Mangrove trees can also serve as a shelter for marine life and for fish so it can preserve life around the beach. Mangrove trees also serve as oxygen producers and as a counterweight to the preservation of coastal environments (Triatmodjo, 1999). Mangrove ecosystem is a plant community that protects the tropical and subtropical coastal areas from waves, storms, tsunamis, and erosion (Blasco dkk. 1996). The role of mangrove forest is as coastal area protector because their roots and their vegetation stem can reduce the strong energy of currents and waves. The structure of the mangrove forests of Sonneratia species with a thickness of $100 \mathrm{~m}$, its root system is able to reduce wave energy by up to $45 \%$, even when the wave height up to the canopy, its leaf arrangement can reduce it up to $50 \%$ (Mazda, 2006). The efficiency of wave energy reduction of magrove forest depends on the species of an ecosystem, the condition of the vegetation community, water level, and the types of wave. Mangrove forest also keep the quality of water which support fishery in coastal and offshore ecosystem. 
(Ronnback, 1999). Moreover, Mangrove forest can be saources of food, building materials, firewood, and medicinal materials (Walters, 2008).

\section{Conclusion}

Erosion is caused by natural and human factors. Natural factors that cause the process of erosion are wind, wave and sedimentation. First, wind blows over the ocean causing waves and currents. The data from the research told that alternative criteria of coastal erosion mitigation in Jerowaru coastal area are Community Empowerment (0,444), Mangrove Cultivation (0,234), Settlement Relocation (0,153), Environmental control (0,85), Stone Grid (0,53), and Government's Role $(0,31)$. The strategies used to anticipate coastal erosion are the installation of stone grid structure in coastal erosion mitigation, a routine community counseling, raising people's awareness toward coastal areas preservation, the relocation of residential area which are badly damaged by coastal erosion, preventing residential development in erosion-prone zone and mangrove cultivation.

\section{References}

Aflaha, Evi. (2014). Benefits of Mangrove as Environmental Conservation in Olaya Village Parigi Sub-District Parigi Mautung Regency. Journal - Geo Tadaluko, UNTAD

Aji Ali Akbar, Junun Sartohadi, Tjut Sugandawaty Djohan, Su Ritohardoyo. (2017). Coastal Erosion, Mangrove Ecosystems and Community Adaptation to Coastal Disasters in Tropical Tropical Countries Journal of Environmental Science Volume 15 Issue 1 (2017): 1-10 ISSN 1829-8907. StudyEnvironmental Science Program (S2). UNDIP

Alif Noor Anna, Suharjo, Retno Woro Kaeksi (2010). Land Use Planning of Coastal Areas Based on Erosion Process in North Coast of Jepara. National seminar of remote sensing and geographic information system I. University of Muhammadiyah. Surakarta .

A.M.Mwakumanya, T.M unyao, E.K.Ucakuwun (2009). Beach width analyses in beach erosion hazard assesment and management at Bamburi beach, Mombasa, Kenya.Journal of Geography and Regional Planning. Vol 2(12), pp 299-309 ISSN 2070-1845.

Coastal Erosion Managemnet Plan (COEMAP) (2000). Departmen Of Land And Natural Resources Land Division Hawai.

Coral Reef Conservation Program 2011-2016 Strategic Plan. (2011). Office of Coastal and Aquatic Managed Areas Florida Department of Environmental Protection.

Coral Reef Conservation Program 2011-2016 Strategic Plan. (2011). Office of Coastal and Aquatic Managed Areas Florida Department of Environmental Protection.

Fitriansyah, Herry. (2012). Sustainability of Coastal Environment Management through Community Empowerment in Kwala Lama Village Serdang Bedagai Regency. Journal of Regional and City Development. Volume 8 (4): 360-370 December 2012.Department of Environmental Protection Bureau of Undip Publisher

Hernandes, Delgado. (2015). The emerging threats of climate change on tropical coastal ecosystem services, public health, local economies and livelihood sustainability of small islands: Cumulative impacts and synergies. Elsevier. MPB-07175; No of Pages 24.

Helman, P, Thomalla, F, Metusela, C \& Tomlinson, R (2010). Storm tides, coastal erosion and National Climate Change Facility, Gold Coast, 37 pp.

Julis, M. (2016). Community Empowerment Strategy Responds to Erosion Hazard in Manub Sub District of Padang Selatan Sub-district of Padang City. Thesis Master of Education S2 Geography FIS UNP. Padang.

Laws of the republic Indonesia No 27. 2007. Management of Coastal Areas and Small Islands. 
Laws of the republic Indonesia No 24. 2007. Disaster management.

Mark Spalding, Anna Mcivor, Femke Tonnejik, Susanna Tol and Pieter Van Ejik. (2014). Magroves For Coastal Defence. Wetlands Internasional and The Nature Conservancy.

National Board for Disaster Management. (2013). Indonesia Disaster Risk Index. Sentul: Directorate of Disaster Risk Reduction.

National Board for Disaster Management. (2008). Guidelines for Preparation of Disaster Management Plan. Jakarta

Nopparat Nasuchon. (2009). coastal management and community management in malaysia, vietnam, cambodia and thailand, United Nations-Nippon Foundation Fellow 2008 - 2009. Division For Ocean Affairs and the Law Of The Sea Office Of Legal Affairs, The United Nations, New York, 2009.

Pristianto, Djuni. (2012). The Role Of Government, Society and Institutions In Disaster Management. Bogor Agricultural Institute's Disaster Study Center.

Ray-Yeng Yang, Ying-Chih Wu and Hwung-Hweng-Hwung (2012). Beach Erosion Management with the Application of Soft Countermeasure in Taiwan.

Regulation of the Minister of Public Housing No 10 (2014). Natural Disaster Mitigation Guidelines for Housing and Settlement Areas.

Thomas L. Saaty, (2001). Decision Making for Leaders Vol. II of the AHP Series, 315 pp., RWS Publ., (new ed). ISBN 0-9620317-8-X.

Triatmodjo, Bambang. (1999). Beach Engineering. Yogyakarta: Beta Offset Yogyakarta.

Triatmodjo, Bambang. 2008. Port. Yogyakarta: Beta Offset Yogyakarta.

Thampanya U , J.E. Vermaat, Sinsakul N. Panapitukkul. (2005). Coastal erosion and mangrove progradation of Southern Thailand. Journal Of Estuarine Coastal and Shelf Science. Elsavier 